\title{
Odontometric Analysis of Permanent Mandibular Canine to Determine Sexual Dimorphism: A Preliminary Study
}

\author{
Bajracharya $\mathrm{M}^{1 *}$, Omar $\mathrm{BK}^{2}$, Maharjan $\mathrm{SK}^{3}$ \\ ${ }^{1}$ Assistant Professor, Department of Anatomy, People's Dental College and Hospital, Shorakhutte, Kathmandu, Nepal \\ ${ }^{2}$ Professor, Department of Anatomy, Nepalgunj Medical College, Nepalgunj, Nepal \\ ${ }^{3}$ Assistant Professor, Department of Prosthodontics and Maxillofacial Prosthetics, \\ People's Dental College and Hospital, Shorakhutte, Kathmandu, Nepal
}

\begin{abstract}
Introduction: Crown diameters of a teeth are reasonably accurate predictors of sex and are good adjuncts for sex determinations. The aim of the study was to determine the reliability of mesiodistal width of mandibular canine in sexual dimorphism.

Materials and methods: Medical students of Nepalgunj Medical College, Chisapani, Banke, Nepal were selected for data collection. Sample consisted of 300 subjects which included 150 males and 150 females of age group 18-25 years. The mesiodistal width of the mandibular right and left canine teeth were recorded by Vernier calliper. Descriptive statistical analysis was done from odontometric measurements data to calculate sexual dimorphism for mandibular right and left canine. The student $\mathrm{t}$-test was used to determine the level of significance among the parameters measured.

Results: The mean values for mesiodistal width of mandibular right canine for male and female subjects were $7.1665 \pm 0.28576$ and $6.3777 \pm 0.37875$ respectively. The sexual dimorphism for mandibular right canine was calculated to be $12.368 \%$. The mean values for mesiodistal width of mandibular left canine for male and female subjects were $7.3875 \pm 0.35506$ and $6.2847 \pm 0.41115$ respectively. The sexual dimorphism for mandibular left canine was calculated to be $17.5 \%$.

Conclusion: Statistical analysis showed significant sexual dimorphism in odontometric analysis of permanent mandibular canines between male and female with the mandibular left canine showing the highest percentage.
\end{abstract}

Key words: Odontometric analysis, Mandibular canine, Sexual dimorphism

\section{Introduction}

Cexual dimorphism refers to the differences $\checkmark$ in size, stature and the appearance between male and female in relation to various structures of the human body. The skeleton as a whole in general and individual bones such as vertebrae, especially the first cervical (or Atlas) vertebra, sacrum, pelvis, clavicle in particular have been reported to be of great significance in relation to the sex differences in various population. Odontometric analyses have also been reported

*Corresponding Author

Dr. Mangesh Bajracharya, Assistant Professor Department of Anatomy,

People's Dental College and Hospital, Shorakhutte, Kathmandu, Nepal

E-mail: anatomist198@gmail.com to be of immense value for sex identification because no two mouths are alike ${ }^{1}$. In cases of mass disasters, where there are no personal items of the victims, or the circumstances of the accident destroys soft tissue of body that might help us for identification of the individual; we can use techniques such as facial reconstruction; use of different laboratory procedures of bones and identification from DNA study etc. But of all morphological structures including human skeleton there is only one structure that does not change in size or shape after the initial development that is the teeth.

In the process of identification of skeletal human remains subjected to deterioration by chemical or physical agent, teeth play a 
fundamental role ${ }^{2}$. Teeth have been identified to show extreme durability because of being the hardest as well as chemically the most stable tissues in the body. The permanent canines offer definite advantages as: they are less affected by periodontal diseases, are the least extracted ones, are exposed to less plaque, show minimal abrasion from brushing and are the last teeth to be extracted with advancing age ${ }^{3}$. The above causes led earlier workers to use measurements of mesiodistal and buccolingual width of practically all human teeth in the assessment of the sexual dimorphism in world-wide population. Mandibular canines are regarded to show the greatest sexual dimorphism amongst all teeth ${ }^{4,5}$.

Studies on the mandibular canines by earlier workers $^{5-9}$ indicated them as key teeth for personal identification of individuals. Teeth in general, have been reported to be larger in size in males when compared with those of female ${ }^{10-15}$

Only scanty reports are available on the abovementioned dental measurements and associated indices in Nepalese population. Hence, the present work related with the mesiodistal widths of the mandibular canine would be of great importance for comparison with the data analysed by the earlier workers in non-Nepalese subjects.

\section{Materials and Methods}

This cross-sectional study was conducted in Nepalgunj Medical College, Department of Anatomy after the approval from the ethical review board. Duration of study was 12 months. Medical students of Nepalgunj Medical College, Chisapani, Banke, Nepal were selected for data collection. Each individual was informed regarding objective and method of the study and written consent was obtained from them. Personal informations regarding name, age and sex were recorded. The resultant study sample consisted of 300 subjects which included 150 males and 150 females of age group 18-25 years. Inclusion criteria of the subjects were medical students of Nepalgunj Medical College between ages of 18-25 years, with healthy anterior teeth free of any pathology, with standard over-jet and overbite (between 2 to $3 \mathrm{~mm}$ ) and absence of spacing and rotation in anterior region of the jaw.

Missing anterior teeth on either side with prosthesis on concerned teeth and past history of any trauma/ surgical treatment on the concerned teeth were excluded in this study.

\section{Measurement of Mesiodistal width}

Each individual was asked to sit comfortably on a chair. Intraoral examination of the anterior mandibular teeth was done to detect occlusion, over-jet, overbite, and rotation and/or malpositioning. The mesial and distal surfaces of right and left mandibular canine were identified (figure 1) and the distance between the crests of the curvature on the mesial and distal surface was recorded by Vernier caliper (figure 2).

\section{Calculation of Sexual dimorphism}

From the above obtained odontometric measurements, sexual dimorphism for right and left mandibular canine was calculated by using following formula ${ }^{17}$.

Sexual Dimorphism $=\left[\left(\mathrm{X}_{\mathrm{m}} \div \mathrm{X}_{\mathrm{f}}\right)-1\right] \times 100 \%$

Where, $\mathrm{X}_{\mathrm{m}}=$ mean mesio-distal width in males: $\mathrm{X}_{\mathrm{f}}=$ mean mesio-distal width in females.

\section{Statistical Analysis}

Descriptive statistics were calculated from the obtained measurements and indices. For each parameter the differences between the means for the male and female were assessed for statistical significance by using SPSS version 16 at the $\mathrm{p}=<0.05$ level of significance. The student t-test was used to determine the level of significance among the parameters measured. 


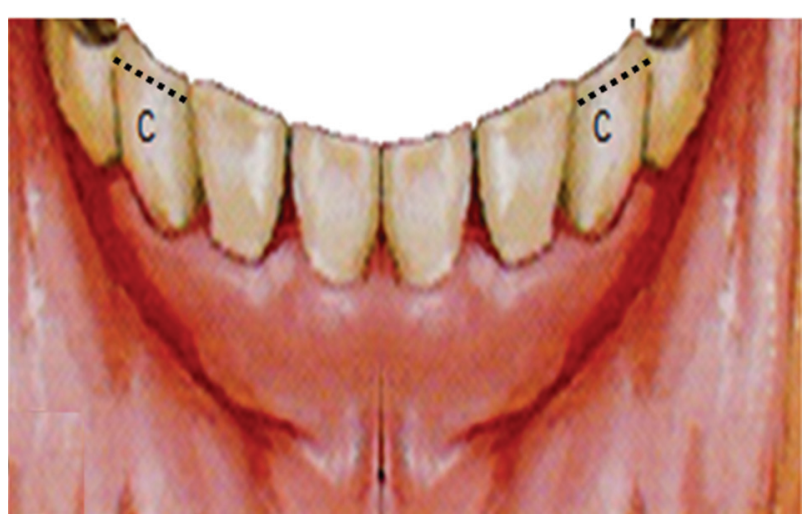

Figure 1: Identification of mesial and distal contact area for measuring mesiodistal width.

\section{Results}

\section{Mesiodistal width of Mandibular Right Canine:}

The mean mesiodistal width of mandibular right canine for male and female subjects (Table1) were 7. $1665 \pm 0.28576$ and $6.3777 \pm 0.37875$ respectively. The mean value for total sample was $6.7721 \pm 0.51794$. Independent t-test revealed $\mathrm{p}>0.001$, which was statistically highly significant. The sexual dimorphism for mandibular right canine was calculated to be $12.368 \%$.

\section{Mesiodistal width of Mandibular Left Canine}

The mean mesiodistal width of mandibular left canine for male and female (Table 2) were $7.3875 \pm 0.35506$ and $6.2847 \pm 0.41115$ respectively. The mean value for total sample was

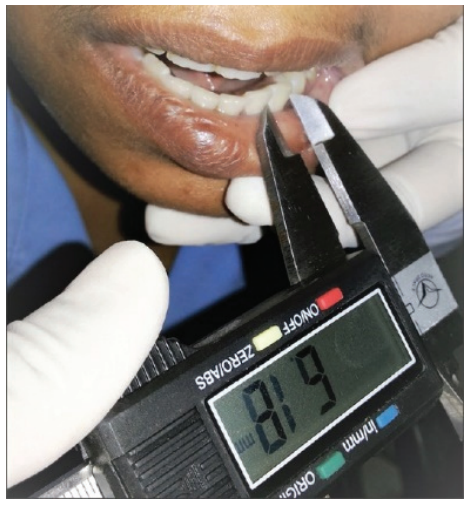

Figure 2: Measurement of mesiodistal width using Vernier caliper

$6.8361 \pm 0.67240$. Independent t-test revealed $\mathrm{p}>0.001$, which was statistically significant. The sexual dimorphism for mandibular left canine was calculated to be $17.5 \%$.

\section{Discussion}

Gender determination in damaged and mutilated dead bodies or from skeletal remains constitutes the foremost step for identification in medicolegal examination and bioarchaeology. Whenever it is possible to predict sex, identification is simplified because the missing person of only that sex need to be considered ${ }^{18}$. Although DNA profile give accurate results, yet odontometric parameters has to be used for determination of sex in a large population because of being simple, reliable, cost effective and easy.

Table 1: A comparison of descriptive statistical parameters in mandibular right canine (in $\mathrm{mm}$ ) in male and female groups.

\begin{tabular}{|c|c|c|c|c|c|}
\hline \multirow{2}{*}{ Parameters } & Male(n=150) & Female $(\mathbf{n}=\mathbf{1 5 0})$ & Total $(\mathbf{n}=\mathbf{3 0 0})$ & $\mathbf{t}$ & $\mathbf{\text { t-test }}$ \\
\hline Mean & 7.1665 & 6.3777 & 6.7721 & & \\
\hline S.D & \pm 0.28576 & \pm 0.37875 & \pm 0.51794 & & \\
\hline S.E & 0.02333 & 0.03092 & 0.02990 & & \multirow{2}{*}{$0.000(\mathbf{S})$} \\
\hline Minimum & 6.24 & 5.37 & 5.37 & 20.362 & \\
\hline Maximum & 7.78 & 6.98 & 7.78 & & \\
\hline Range & 1.55 & 1.61 & 2.41 & & \\
\hline
\end{tabular}

$S=$ Significant $;$ NS $=$ Non-significant 
Table 2: A comparison of descriptive statistical parameters in mandibular left canine (in $\mathrm{mm}$ ) in male and female groups.

\begin{tabular}{|c|c|c|c|c|c|}
\hline Parameters & Male(n=150) & Female(n=150) & Total(n=300) & \multicolumn{2}{|c|}{ t-test } \\
\cline { 1 - 3 } & & & 6.8361 & & \\
\hline Mean & 7.3875 & 6.2847 & \pm 0.67240 & & \\
S.D & \pm 0.35506 & \pm 0.41115 & 0.03882 & & \\
\hline S.E & 0.02899 & 0.03357 & 4.88 & \multirow{2}{*}{24.863} & \multirow{2}{*}{$0.000(\mathbf{S})$} \\
\hline Minimum & 6.99 & 4.88 & 8.74 & & \\
\hline Maximum & 8.74 & 7.04 & 3.86 & & \\
\hline Range & 1.75 & 2.16 & & \\
\hline
\end{tabular}

$\mathrm{S}=$ Significant; NS= Non-significant

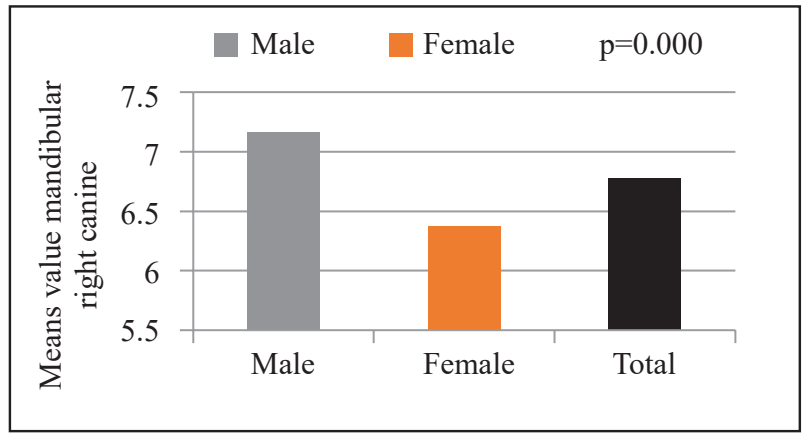

Figure 1: Comparison of Mesiodistal width of Mandibular Right Canine

There are differences in odontometric features in specific population, even within the same population in the historical and evolutional context, it is necessary to determine specific population values in order to make identification possible on the basis of dental measurements ${ }^{19}$. Doris et al have indicated that early permanent dentition provide the best sample for tooth size measurements because early adulthood dentition has less mutilation and attrition ${ }^{20}$. Consequently, the effect of these factors on the actual mesiodistal width would be minimum. Thus only subjects in the 18-25 years age group were included in the study sample. Most commonly, the width and length of the crown were taken in consideration, among this former is considered to be more reliable ${ }^{21}$.

In the present study, the mean values for mesiodistal width was found to be $7.16 \pm 0.28 \mathrm{~mm}$ in males and $6.37 \pm 0.37 \mathrm{~mm}$ in female on right side whereas $7.38 \pm 0.35 \mathrm{~mm}$ in males and $6.28 \pm 0.41 \mathrm{~mm}$ in females on left

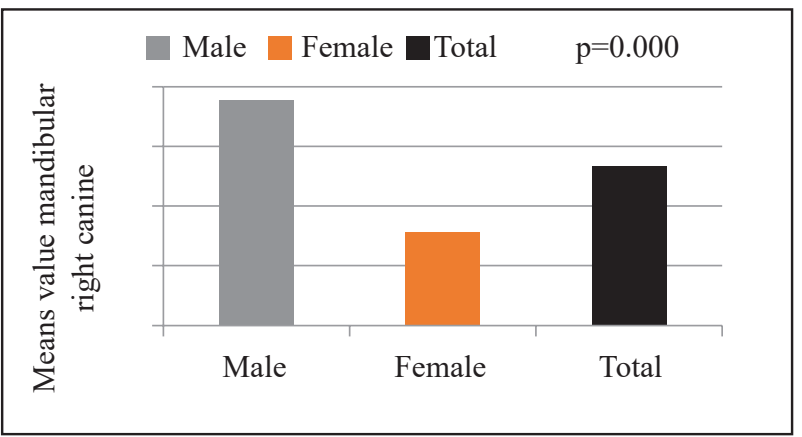

Figure 2: Comparison of Mesiodistal width of Mandibular Left Canine

side. The percentage of sexual dimorphism was found $12.36 \%$ and $17.5 \%$ on right and left sides respectively. In the study performed by Kaushal et $\mathrm{al}^{5}$ in North Indian populations in 60 subjects of age 17-21 years, the mean values for mesiodistal width on right side was $7.22 \pm 0.28 \mathrm{~mm}$ in males and $6.69 \pm 0.25 \mathrm{~mm}$ in females; on left side, it was $7.29 \pm 0.29 \mathrm{~mm}$ in males and $6.69 \pm 0.32 \mathrm{~mm}$ in females. The values were found statistically highly significant when compared between male and female. The left canine showed the maximum percentage of sexual dimorphism of $8.89 \%$.

In the study conducted by Vishwakarma and Guha $^{22}$ in 90 males and 90 females of age group 17-23 years, the mean mesiodistal width of mandibular canines were: $7.40 \pm 0.42 \mathrm{~mm}$ in males and $6.50 \pm 0.49 \mathrm{~mm}$ in females on right side and $7.40 \pm 0.44 \mathrm{~mm}$ in males and $6.70 \pm 0.52 \mathrm{~mm}$ in females on left side. In their study. percentage of sexual dimorphism were found to be $12.51 \%$ in right side and $10.15 \%$ in left side, whereas 
in present study left mandibular canine showed maximum percentage of sexual dimorphism than right.

In the study performed by Saboia et $\mathrm{a}^{23}$ in Brazil, the mean mesiodistal width of mandibular canines were: $7.29 \pm 0.45 \mathrm{~mm}$ in males and $6.69 \pm 0.43 \mathrm{~mm}$ in females on right side and $7.24 \pm 0.41 \mathrm{~mm}$ in males and $6.85 \pm 0.2 \mathrm{~mm}$ in females on left sides, statistically significant differences were observed maximum for left mandibular canine than the right

\section{Conclusion}

Crown diameter of the tooth is a valuable tool and provide significant information on human evolution, biological alterations and in forensic and clinical odontology. Tooth crown diameters are reasonably accurate predictors of sex and are good adjuncts for sex determinations. The mean value obtained from the present study showed significant sexual dimorphism in mandibular canines between male and female with the mandibular left canine showing the highest percentage of sexual dimorphism.

\section{References}

1. Srivastava PC. Correlation of odontometric measures in sex determination JU Indian Acad Forensic Med 2011;32(1):56-61.

2. Rö-sing FW. Sexing immature human skeletons. J Hum Evol 1983; 12:149-55.

3. Anderson DL, Thompson GW, Interrelationship and sex differences of dental and skeletal measurements. J Dent Res 1973;52:431-38.

4. Garn SN, Lewis AB, Swindler DR, Kerewsky RS, Genetic control of sexual dimorphism in tooth size. J Dent Res 1967;46:963-72.

5. Kaushal S, Patnaik VVG, Agnihotri G. Mandibular canines in sex determination. J AnatSoc India 2003 2003;52(2):119-24.

6. Kumar N. Rao G. Rao NN, Pai LM. Mandibular canine index-A clue for establishing sex identity. Forensic SciInt 1989;42(1):249-54.

7. Yadav S. Nagabhushan D. Rao BB, Mamtha GP. Mandibular canine index in establishing sex identity. Indian J Dent Res 2002;13:143-6.

8. Reddy MV, Saxena S. Mansal P. Mandibular canine idex as a sex determinant: A study on the population of Western Uttar Pradesh. J Oral and Maxillo facial Path 2008;122):56-9.

9. Moorrees CTA, Thomsen SO, Jensen E, Yen PKJ. Mesiodistal crown diameters of the dediduous and permanent teeth in individuals, $\mathrm{J}$ Dent Res 1957;36:39-47.

10. Barrett MJ. Brown T, MacDonald MR. Dental observations on Australian aborigines: mesiodistal crown diameters of permanent teeth, Aus Dent J 1963;8:150-5.

11. Richardson ER, Malhotra SK, Mesiodistal crown dimension of the permanent dentition of American Negroes. Amer J Orthodontics 1975;68:157-64.

12. Margetts B, Brown T. Crown diameters of the deciduous teeth in Australian Aboriginals, Am J PhysAnthropol 1978;48:493-502.

13. Axelsson G, Kirveskari P. Crown size of permanent teeth in Icelanders. ActaOdontScand 1983;41:181-6.

14. Axelsson G, Kirveskari P, Crown size of deciduous teeth in Icelanders. ActaOdontScand 1984;42:339-43.

15. Buschang $\mathrm{PH}$, Demirjian A, Cadotte L, Permanent mesiodistal tooth size of FrenchCanadians. Can Dent Assoc J 1988;54:441-4.

16. Hunter WS, Priest WR. Errors and discrepancy in measurement of tooth size. 3 Dent Res 1960:39:405-14.

17. Garn SM,LeiwsAB,kerewsky RS. The relationship between sexual dimorphism in tooth size and body size as studied within families. Arch Oral Biol 1967; 12:999-301.

18. Dahberg AA. Dental traits as identification tools. Dent Prog 1963;3:155-60.

19. Iscan MY, Kedici SP. Sexual variation in bucco-lingual dimensions in Turkish dentition, Forensic SciInt 2003;127;160-4.

20. Doris JM, Bernard BW, Kuftinec MM, Stom D. A biometric study of tooth size and dental crowding. Am J Orthod. 1981;79:326-36.

21. Nagle RJ,Sears VH. Anterior tooth arrangement. In;CompleteDenturest $\left(1^{\text {st }}\right.$ edition). St.Louis: The CV Mosby Company; 1958. p.353. 
22. Vishwakarma N, Guha R. A study of sexual dimorphism in permanent mandibular canines and its implications in forensic investigations. Nepal Med Coll J 2011;13(2):96-99.
23. Saboia TM, Tannure PN, Liuz RR, Costa MC, Granjeiro JM, Kuchler EC, Antunes LS. Sexual dimorphism involved in the mesiodistal and buccolingual dimensions of permanent teeth. Dentistry 3000 2013:1(1)1-5. 